\title{
КОНСТИТУТИВНІ ТА ПЕРЕТВОРЮВАЛЬНІ ВЛАСТИВОСТІ РІШЕННЯ СУДУ ЯК ПРАВОВОГО ЗАСОБУ ЗАХИСТУ СУБ'ЄКТИВНИХ ЦИВІЛЬНИХ ПРАВ НА НЕРУХОМЕ МАЙНО
}

Постановка проблеми. Цивільний оборот нерухомості, будучи одним із найбільш фінансово ємних ринків, потребує ефективних механізмів захисту суб'єктивних цивільних прав і законних інтересів його учасників, адже обіг великого обсягу коштів пов'язується 3 підвищеними ризиками, що, своєю чергою, зумовлює необхідність існування інструментів їх мінімізації.

За своєю телеологічною спрямованістю захист суб'єктивних цивільних прав на нерухоме майно передбачає недопущення порушення відповідного суб'єктивного цивільного права за реальної загрози його порушення, припинення порушення суб'єктивного цивільного права та/або відновлення порушеного суб'єктивного цивільного права. При цьому одними з найбільш поширених і ефективних способів захисту суб'єктивних цивільних прав на нерухоме майно нині виступають способи судового захисту. Безпосереднім правовим засобом захисту в такому разі слід визнати рішення суду.

Однак, незважаючи на те що способи судового захисту неодноразово ставали предметом дослідження в рамках цивілістичних наукових пошуків, проблема ролі рішення суду в механізмі недопущення порушення суб' $є$ тивних цивільних прав на нерухоме майно, припинення такого порушення або ліквідації його наслідків, зокрема шляхом відновлення порушених прав, залишається одним із дискусійних моментів сучасної цивілістики. Спірним питанням $€$ здатність рішення суду впливати на обставини правової реальності, зокрема спричиняти виникнення, перехід або припинення суб'єктивних цивільних прав на нерухоме майно, тобто конституювати суб'єктивні цивільні права (спричиняти їх виникнення) або перетворювати їх (змінювати чи припиняти).

Вирішення цієї проблеми є передумовою комплексного й усебічного розуміння механізму судового захисту суб'єктивних цивільних прав на нерухоме майно та способів досягнення відповідних юридичних результатів.

Аналіз останніх досліджень i публікацій. Проблеми судового захисту суб'єктивних цивільних прав на нерухоме майно, а також правової природи рішення суду в механізмі його здійснення розглядалися такими вченими-правниками, як: С.С. Алексєєв, I.B. Андронов, I.В. Венедіктова, I.B. Жилінкова, О.С. Iоффе, Т.С. Ківалова, В.С. Ковальська, A.В. Коструба, О.О. Кот, Н.С. Кузнєцова, О.Д. Кутателадзе, Р.А. Майданик, В.В. Надьон, О.О. Отраднова, Д.В. Роженко, М.О. Рожкова, Я.М. Романюк, І.В. Спасибо-Фатєєва, Л.Г. Талан, Р.О. Халфіна, Г.Г. Харченко, С.М. Хорунжий, Я.М. Шевченко, Р.Б. Шишка, О.Я. Явор, В.Л. Яроцький та ін. 
Постановка завдання. Мета статті полягає у визначенні правової природи рішення суду як правового засобу захисту суб'єктивних цивільних прав на нерухоме майно в аспекті наявності або відсутності у нього таких властивостей, як конститутивність та перетворювальність.

Основний матеріал дослідження. У сучасних цивілістичних дослідженнях спостерігається поступове збільшення прихильників наукової концепції, в рамках якої рішення суду розглядається як юридичний факт, тобто обставина правової реальності, що здатна трансформувати інші обставини, зокрема спричиняти виникнення, перехід або припинення суб'єктивних цивільних прав, у тому числі на об'єкти нерухомого майна. Наприклад, М.О. Рожкова вказує на те, що здебільшого ухвалення судового рішення виступає як самостійний юридичний учинок, спрямований на захист прав одного з учасників цивільного правовідношення, юридична справа яких стала предметом судового розгляду [1, с. 356]. Здатність рішення суду виступати в окремих випадках юридичним фактом і спричиняти, зокрема, окреслені наслідки визнається i такими вченими, як I.В. Андронов [2, с. 206], В.С. Ковальська [3, с. 138], О.Д. Кутателадзе [4, с. 136], В.В. Надьон [5, с. 50], Д.В. Роженко [6, с. 131], Л.Г. Талан [7, c. 80$]$,

Водночас противники такого підходу намагаються вивести розуміння рішення суду за межі категорії юридичного факту шляхом протиставляння останнього й актів застосування норм права. Хоча при цьому дехто 3 них i не заперечує наявність у судового рішення здатностей впливати на динаміку обставин правової реальності. Одним із науковців, які підтримують такий підхід, є С.M. Хорунжий. Учений указує на те, що судове рішення, безумовно, здійснює вПлив на структуру і динаміку суспільних відносин, проте не як особливий юридичний факт, а як дія законної сили судового рішення. Зокрема, суб'єктивне цивільне право здійснюється в рамках складених та існуючих правовідносин. Судове рішення визнає (санкціонує) існуюче суспільне відношення (до змісту якого входить відповідне суб'єктивне цивільне право), надаючи йому статус безспірного правовідношення. Із цього, на переконання вченого, слідує, що, здійснюючи судовий захист суб'єктивного цивільного права, акт суду не набуває значення певного конститутивного елементу цивільного (матеріального) правовідношення, проте залишається актом правозастосування [8, с. 97]. Певною мірою це проміжна наукова позиція між визнанням за рішенням суду виключно інформативних властивостей i його здатності конституювати або перетворювати елементи правової реальності, зокрема суб'єктивні цивільні права на нерухомість. Тобто, відповідно до цієї позиції, рішення суду підтверджує певні обставини, посилюючи їх з юридичного погляду, хоча і не спричиняє їх виникнення, зміну або припинення.

Своєю чергою, Г.Г. Харченко будує свої міркування на протиставлянні юридичного факту та акту правозастосування, зазначаючи, що рішення суду не можуть бути підставами виникнення та припинення речового права саме у зв'язку з їх правозастосовним характером [9, с. 179].

У контексті окреслених вище наукових положень слід відзначити, що теоретичний підхід, у рамках якого за рішення суду не визнається здатність забезпечувати встановлення, перехід або припинення суб'єктивних цивільних прав на нерухоме майно чи встановлення, зміну або припинення правовідносин щодо нерухомості, у цілому наділений значною вадою. Вона проявляється в тому, що прихильники такого підходу, заперечуючи відповідні властивості судових рішень, не піддають комплексному аналізу можливі 
варіації розвитку подій, якщо рішення суду не ухвалюється.

При цьому відповідні вади особливо чітко проявляються у справах про визнання недійсними правочинів, на підставі яких відбувся перехід права власності на нерухоме майно або передача нерухомого майна у користування. Як приклад можна навести постанову Вищого господарського суду України від 08 жовтня 2012 р. у справі № 5004/822/11(02/30-92). Як убачається з цієї постанови, рішенням господарського суду Волинської області від 22 лютого 2010 р. задоволено позов ТОВ «Луцьк-Оздоббуд» до ЗАТ «Демидівська спеціалізована пересувна механізована колона № 3» визнано недійсним договір купівлі-продажу нерухомого майна від 02 жовтня 2008 р. й зобов'язано ЗАТ «Демидівська спеціалізована пересувна механізована колона № 3» повернути відповідні об'єкти нерухомого майна ТОВ «Луцьк-Оздоббуд» [10]. Ця справа має продовження, проте для наочності піднятої проблеми необхідно припустити, що це рішення господарського суду Волинської області набрало законної сили. У такому разі в силу втрати чинності правовою підставою переходу права власності на відповідні приміщення від ТОВ «Луцьк-Оздоббуд» до ЗАТ «Демидівська спеціалізована пересувна механізована колона № 3» власником зазначеного нерухомого майна залишається ТОВ «ЛуцькОздоббуд», тобто відчужувач за зазначеним договором.

Слідуючи підходу, відповідно до якого рішенням суду лише встановлюється наявність або відсутність певних обставин правової реальності, виходить, що в окресленому випадку суд установлює факт недійсності правочину, вчиненого у формі договору. Із цього витікає, що відповідна обставина правової реальності, тобто недійсність, існувала і до ухвалення судом рішення, тобто передувала йому. Суд лише підтверджує існування відповідної обста- вини, однак не надає правочину характеру недійсного. Правочин є недійсним у силу наявності вад у підставах або умовах його чинності в момент учинення, а не в силу набрання рішенням суду законної сили.

Проте в такому разі необхідно поставити таке запитання: а що трапляється 3 відповідним правочином, якщо він не оспорюється в судовому порядку? 3 окресленої вище наукової концепції, яка заперечує існування за рішенням суду властивості спричиняти виникнення, перехід або припинення суб'єктивних цивільних прав на нерухоме майно, мало б слідувати, що такий правочин $є$ недійсним, хоча це й не встановлено судом. I саме у цій частині проявляється вразливе місце відповідної наукової концепції.

Як відомо, відповідно до одного 3 найбільш поширених підходів, недійсні правочини поділяються на нікчемні та оспорювані, або, як їх ще називають в юридичній літературі, відносно недійсні. Відповідний поділ недійсних правочинів знайшов закріплення і в ст. 215 Цивільного кодексу України (далі - ЦК України) [11]. Різниця між ними саме і полягає в здатності чи нездатності відповідних правочинів спричиняти юридичні наслідки.

Звернення з позовом про визнання правочину недійсним (а не про встановлення нікчемності правочину та/або застосування наслідків нікчемного правочину) [Див.: 12, п. 5] і задоволення такого позову означає, що наведений вище правочин (договір купівлі-продажу нерухомого майна) $€$ оспорюваним, тобто відносно недійсним. Із цього приводу Пленум Вищого господарського суду України у Постанові від 29 травня 2013 р. № 11 «Про деякі питання визнання правочинів (господарських договорів) недійсними» вказав, що за змістом частини другої ст. 215 ЦК України нікчемний правочин на відміну від оспорюваного $€$ недійсним незалежно від наявності чи відсутності 
відповідного рішення суду (п. 2.5.2) [13, п. 2.5.2].

Із цієї тези слідує, що недійсність оспорюваного правочину безпосередньо залежить від рішення суду, навіть незважаючи на те що правочин, визнаний судом недійсним, $€$ недійсним із моменту його вчинення (частина перша ст. 236 ЦК України) [11, ст. 236]. Тобто в такому разі рішення суду має певною мірою ретроспективне значення.

Окрім того, у контексті оспорюваних правочинів необхідно зважати на ст. 204 ЦК України, якою запроваджується презумпція правомірності правочину, у зв'язку з чим правочин є правомірним, якщо його недійсність прямо не встановлена законом або якщо він не визнаний судом недійсним [11, ст. 204].

Окреслене створює підгрунтя для висновку, що значення рішення суду у відповідних випадках виходить за межі суто фіксації певних обставин правової реальності і безпосередньо наділяється конститутивними або перетворювальними властивостями. Це підкреслюється, зокрема, тим, що оспорюваний правочин $€$ дійсним до моменту визнання його недійсним за рішенням суду. У зв'язку із цим у відповідній ситуації саме рішенню суду (а якщо бути більш точними набранню ним законної сили) відводиться роль «поворотної» обставини, яка запускає механізм відновлення суб'єктивних цивільних прав учасника відповідного правочину.

Також необхідно зважати на те, що фактичні обставини свідчать про те, що у разі визнання правочину недійсним у судовому порядку відбувається все ж таки «згортання» юридичних наслідків, а не констатація факту, що відповідні обставини (наслідки) ніколи не наставали. Лише за допомогою такого прийому, як фікція в умовах правореалізації і правозастосування, вважається, що відповідні наслідки не мали місця в правовій реальності, хоча, як уба- чається, насправді протягом певного часу вони все ж таки існували. У зв'язку із цим хоча в аналізованому випадку не можна стверджувати про зворотний перехід права власності від набувача до відчужувача (принаймні у зв'язку з тим, що правовстановлююча підстава для права власності відчужувача залишається незмінною), однак окреслені вище обставини свідчать про те, що відбувається припинення права власності у набувача i його виникнення у відчужувача.

Водночас варто погодитися і з тим, що здебільшого рішенням суду, дійсно, лише підтверджуються чи спростовуються певні обставини правової реальності і воно не спричиняє жодних правовстановлюючих, правозмінюючих або правоприпиняючих юридичних наслідків. Такі рішення суду ухвалюються у тому числі за результатами розгляду справ за позовами про визнання права власності на об’єкти нерухомого майна. Як приклад можна навести Постанову Касаційного господарського суду у складі Верховного Суду від 29 березня 2018 р. у справі № $904 / 4573 / 16$, якою залишено без змін, зокрема, рішення Господарського суду Дніпропетровської області від 22 грудня 2016 р., яким, зокрема, визнано право власності ПП «ВанПур» на автостоянку, об'єкт нежитлової нерухомості. Рішення суду першої інстанції вмотивоване, зокрема, тим, що відповідач $є$ недобросовісним набувачем, власником майна $€$ позивач і при цьому воно вибуло з його володіння не 3 його волі, за прийнятим судом неправомірним рішенням, яке в подальшому було скасовано судом апеляційної інстанції [14]. Хоча не всі рішення про визнання права власності наділені виключно зазначеними властивостями. Окремі з них мають яскраво виражені конститутивні (правовстановлюючі) характеристики. До різновиду таких судових рішень можна віднести рішення суду про визнання права власності за набувальною давністю, яке $є$ елементом 
юридичного складу - підстави виникнення відповідного суб'єктивного цивільного права (ч. 4 ст. 344 ЦК України) [11, ст. 344].

Висновки і перспективи подальших досліджень. Таким чином, проведений аналіз показує, що рішення суду наділене здатністю не лише інформувати учасників цивільних правовідносин про наявність або відсутність певних обставин правової реальності (практично кожне рішення суду, ухвалене в позовному провадженні, наділене такою здатністю незалежно від змісту резолютивної частини), а й спричиняти виникнення, перехід або припинення суб'єктивних цивільних прав, у тому числі на об'єкти нерухомого майна.

Зважаючи на те, що відповідне рішення суду являє собою основний інструмент захисту суб'єктивних цивільних прав, необхідно констатувати таке: 1) суб'єктивне цивільне право на нерухоме майно може бути захищене, зокрема, шляхом виникнення, переходу та/або припинення суб'єктивного цивільного права на підставі рішення суду, тобто шляхом ухвалення конститутивного або перетворювального рішення; 2) суб'єктивне цивільне право на нерухоме майно може бути захищене у тому числі судовим рішенням про визнання, яким підтверджується існування відповідного суб'єктивного цивільного права.

Повне заперечення наведених тез, по суті, повністю заперечує охоронну властивість судового рішення, a їх часткове заперечення змушує замислитися над існуванням винятків із відповідних випадків. У цьому сенсі слід зважати на те, що принаймні рішення, що ухвалюються в рамках окремого провадження, можуть слугувати не засобом захисту суб'єктивного цивільного права на нерухоме майно, а передумовою такого захисту. Проте поглибити одержані результати й отримати нові наукові висновки допоможе окремий аналіз юридичних механізмів захисту суб'єктивних цивільних прав на підставі обох видів судових рішень.

Статтю присвячено розгляду конститутивних та перетворювальних властивостей рішення суду в механізмі захисту суб'єктивних ициільних прав на нерухоме майно.

Аналізу піддано теоретичні положення двох протилежних наукових концепцій щуодо правової природи рішення суду як правового засобу захисту суб'єктивних цивільних прав. Автор зазначає, що нині в циивілістичній науці спостерігається поступове збільшення прихильників наукової концепції, у рамках якої рішення суду розглядається як юридичний факт, тобто обставина правової реальності, що здатна конституювати або трансформувати інші обставини, зокрема спричиняти виникнення, перехід або припинення суб'єктивних цивільних прав на нерухоме майно. Противники такого наукового погляду відстоюють позицію, щзо рішення суду не наділене здатністю спричиняти відповідні юридичні наслідки, а лище наділяе характером безспірних певні обставин правової реальності. У рамках такого підходу здійснюються спроби вивести рішення суду за межі його розуміння як юридичного факту з одночасним обтрунтуванням його правозастосовної природи.

Звертаючись до положень чинного изивільного законодавства України, щзо визначають порядок визнання недійсними оспорюваних правочинів, автор демонструе прояв конститутивних та перетворювальних властивостей судових рішень на прикладі конкретної ситуації із судової практики, пов'язаної з визнанням договору купівліпродажу нерухомості недійсним. Підкріплюючи свою позицію аргументами, автор зазначає, що $у$ 
разі визнання правочину щодо нерухомості недійсним у судовому порядку відбувається «згортання» юридичних наслідків, а не констатація факту, що відповідні наслідки ніколи не наставали. У зв'язку із иим унаслідок визнання недійсним договору купівлі-продажу нерухомого майна відбувається його припинення у набувача $і$ виникнення у відчужувача. При цьому відновлюється чинність відповідної правової підстави набуття права власності набувачем.

Також установлюеться, що судові рішення про визнання права власності на нерухоме майно можуть як підтверджувати обставини правової реальності, зокрема належність права власності позивачу, так і спричиняти виникнення права власності у певної особи.

Ключові слова: рішення суду, захист прав, нерухомість, правочин, речові права.

Spiesivtsev $D$. The constitutive and transformative properties of court's decision as legal mean of protection of subjective civil rights on immovable property

The article is devoted to consideration of constitutive and transformative properties of court's decision in mechanism of protection of subjective civil rights on immovable property.

The theoretical provisions of two opposite scientific theories of legal nature of court's decision as legal mean of protection of subjective civil rights on immovable property are analyzed. The author notes that at present it is traced the trend of support the scientific concept according to which the court's decision is considered as juridical fact i.e. circumstance of juridical reality that can constitute or transform other circumstances, particularly can cause the emergence, transfer or termination of subjective civil rights on immovable property. The opponents of such concept defend a position according to which the court's decision has no characteristics that allows it cause appropriate juridical consequences. In their opinion the court's decision can only make some circumstances of juridical reality indisputable. Within such approach scientists make attempts to consider legal nature of court's decision abroad of juridical facts concept. But at the same time they admit that such decision is an act of right-enforcement.

Basing on legislative provisions of current civil legislation of Ukraine that provide the rules of recognition of disputed transaction as invalid the author demonstrates a display of constitutive and transformative properties of court's decision in context of concrete situation from case law related to nullification of immovable property sales-purchase contract. Strengthening his position with arguments the author notes that in case of nullification a real estate transaction through the court it takes place the winding down of the juridical consequences but not a statement of fact that appropriate consequences has never appeared. That's why the nullification of immovable property sales-purchase contract through the court leads to termination of purchaser's property right and to emergence the seller's right of property. At the same time the power of seller's real estate title is restored.

It is also determined that court's decision to recognizing the claimant's right of property on immovable thing can confirm some circumstances of juridical reality, particularly the belonging of property right to the claimant, and cause the arising of property right at defined person.

Key words: court's decision, protection of rights, immovable property, transaction, real rights. 


\section{ЮРИАИЧНИЙ ВІСНИК, 2020/3}

\section{Література}

1. Рожкова М.А. Теории юридических фактов гражданского и процесуального права: понятия, классификации, основы взаимодействия : дисс. ... докт. юрид. наук. Москва, 2010. 418 с.

2. Андронов I.В. Питання класифікації рішень суду в иивільному процесі України. Університетські наукові записки. 2006. № 3-4(19-20). C. 204-207.

3. Ковальська В.С. Рішення суду як правозмінюючий та правоприпиняючий юридичний факт у сімейному праві. Університетські наукові записки. 2013. № 1(45). C. 133-139.

4. Кутателадзе О.Д. До питання про визначення підстав виникнення иивільних прав і обов'язків. Університетські наукові записки. 2005. № 3(15). С. 133-136.

5. Надьон B.В. Рішення суду як підстава виникнення, зміни, припинення та поновлення суб'єктивного цивільного обов'язку (теоретичний та практичнии аспект). Проблеми законності. 2017. Bun. 139. C. 43-51.

6. Роженко Д.В. Щодо поняття та класифікації судових рішень, ухвалених у письмовому провадженні. Наукові праці МАУП. 2013. Bun. 3(38). С. 127-132.

7. Талан Л.Г. До питання про сутність судового рішення в иивільному й господарському судочинстві. Проблеми законності. 2009. Bun. 103. C. 75-81.

8. Хорунжий С.Н. Юридические факты и решение суда с точки зрения защиты субъективного гражданского права и охраняемого законом интереса. Вестник ВГУ. Серия «Право». С. 87-97.

9. Харченко Г.Г. Акти суб'єктів владних повноважень як підстави виникнення та припинення речових прав. Часопис Київького університету права. 2013. № 2. C. 176-180.

10. Постанова Вищого господарського суду України від 08.10.2012, судова справа № 5004/822/11(02/30-92). URL: http: / / reyestr.court.gov.ua/Review / 26431298 (dama звернення: 20.06.2020).

11. Цивільний кодекс України : Закон України від 16.01.2003 № 435-IV. Відомості Верховної Ради України. 2003. № № 40-44. Сm. 356 (зі змінами).

12. Про судову практику розгляду иивільних справ про визнання правочинів недійсними : Постанова Пленуму Верховного Суду України від 06.11.2009 № 9. URL : https: / / zakon.rada.gov.ua/laws / show/v0009700-09\#Text (dama звернення: 20.06.2020)

13. Про деякі питання визнання правочинів (господарських договорів) недійсними : Постанова Пленуму Вищого господарського суду України від 29.05.2013 № 11. URL : https: / / zakon.rada.gov.ua/laws / show/v0011600-13\#Text (dama звернення: 20.06.2020)

14. Постанова Касаційного господарського суду у складі Верховного Суду від 29.03.2018, судова справа № 904 / 4573 / 16. URL: http: / / reyestr.court.gov.ua / Review/ 73081633 (дата звернення: 20.06.2020). 